\title{
Soil properties changes earthworm diversity indices in different agro-ecosystem
}

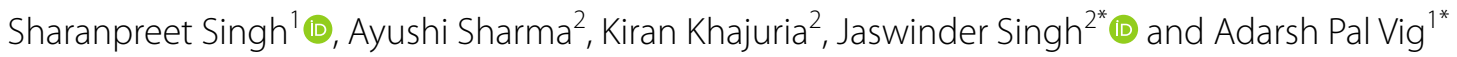

\begin{abstract}
Background: Earthworm communities are generally very sensitive to physico-chemical properties of the soil in different agro-ecosystem i.e. cultivated or non-cultivated which directly or indirectly influence the earthworm survival. The difference in physico-chemical properties of soil at different sites contributed to the formation of population patches for earthworm species. Understanding the physico-chemical properties of soil at a particular site could facilitate the prediction of earthworm species at that site. The objective of the present study was to investigate the diversity, abundance, and distribution of earthworms in cultivated and non-cultivated agroecosystems and their physico-chemical properties affecting the earthworm diversity and abundance.

Results: Total 10 species of earthworms i.e. Amynthas alexandri, Amynthas morrisi, Eutyphoeus incommodus, Eutyphoeus waltoni, Metaphire birmanica, Metaphire houlleti, Metaphire posthuma, Octochaetona beatrix, Perionyx excavatus, and Polypheretima elongata, were reported. Out of all the reported species, Metaphire posthuma was found to be the most abundant earthworm species in both cultivated and non-cultivated agroecosystems with the occurrence at $56.81 \%$ sites. The Shannon-Wiener index $(H)$, Margalef species richness index $\left(D_{M g}\right)$ and Pielou species evenness (E) was ranged from 0 to $0.86,0$ to 0.64 and 0.78 to 1 respectively. The principal component analysis resulted in four principal components i.e. PC1, PC2, PC3 and PC4 which contributing variance (\%) of 22.96, 19.37, 14.23 and 10.10 respectively. The principal component analysis also showed that physico-chemical parameters of soil such as EC, $\mathrm{pH}$, TDS, texture, OC, moisture, etc. play a critical role in earthworm distribution.

Conclusion: The conventional farming system has a negative effect on the earthworm diversity in the soil while the physico-chemical properties of soil also have a determinant effect on the same. Earthworms abundance in the present study have significant direct relation with soil properties at a particular site and vice versa. The diversity indices also change due to the conventional farming system which directly affects the earthworm abundance.
\end{abstract}

Keywords: Abundance, Earthworms, Land use pattern, Soil variables, Principal component analysis

\section{Background}

In agro-ecosystems, earthworm communities are generally very sensitive to physico-chemical properties of the soil which directly or indirectly influence the availability of resources for earthworm survival [1]. The soil structure and its pore size also play a key role in the distribution of

\footnotetext{
*Correspondence: singhjassi75@yahoo.co.in; dr.adarshpalvig@gmail.com ${ }^{1}$ Department of Botanical \& Environmental Sciences, Guru Nanak Dev University, Amritsar, Punjab, India

2 Post Graduate Department of Zoology, Khalsa College, Amritsar, Punjab, India
}

the earthworms within the soil and a minute changes in the same can adversely affect the earthworm's community structure [2]. The richness and diversity of earthworm species were always observed higher in the undisturbed land as compared to disturbed land and likely to increase under favorable soil conditions [3, 4]. In undisturbed land, soil characteristics such as soil quality [5]; $\mathrm{pH}[6]$; moisture [7], as well as soil organic matter [8], affect the diversity and abundance of earthworm's species. On the other hand, disturbed land such as the agricultural field, application of fertilizer [9]; pesticides [10]; tillage 
[11] and soil organization [12] have a strongest effect on earthworm distribution.

Earthworms act as an ecosystem engineer by modifying soil structure and its properties [13-15]. It also change the porosity of the soil by regulating the proportion of organic matter breakdown and nutrient release [16]. The difference in physico-chemical properties of soil at different sites contributed to the formation of population patches for earthworm species. By knowing the physico-chemical properties of soil at a particular site could facilitate the prediction of earthworm species at that site [17]. It is also important to quantify the spatial distribution of earthworms at different agroecosystems in order to understand the effect of abiotic soil processes and to link earthworm abundance to the spatial distribution of macropores in the soil. The information collected on type of earthworm species and their abundance at different habitats may also provide useful information on the efficiency and strength of that ecosystem. Besides the soil physico-chemical properties, the types of the agroecosystem selected at various site i.e. cultivated or noncultivated are also play an important role in earthworms abundance and distribution.

The objective of the present study was to investigate the diversity, abundance, and distribution of earthworms in cultivated and non-cultivated agroecosystems and their physico-chemical properties affecting the earthworm diversity and abundance.

\section{Results}

\section{Earthworm communities and their diversity indices}

We have explored the 44 different sites under cultivated and non-cultivated agroecosystem (Additional file 1: Table S1) under which total 10 species of the earthworms viz. Amynthas alexandri, Amynthas morrisi, Eutyphoeus incommodus, Eutyphoeus waltoni, Metaphire birmanica, Metaphire houlleti, Metaphire posthuma, Octochaetona beatrix, Perionyx excavatus and Polypheretima elongata belonging to two families and six genera were reported. Out of these, 7 species belong to family Megascolecidae (M. posthuma, A. morrisi, A. alexandri, M. houlleti, Polypheretima. elongata, Perionyx excavatus and $M$. birmanica) and three species belong to family Octochaetidae (O. beatrix, E. waltoni and E. incommodus). The distribution of above said species along with their ecological category and diversity indices at each sampling site is given in Table 1. The non-cultivated agroecosystem has high earthworm abundance as compared to cultivated agroecosystem (Fig. 1a). The cultivated and non-cultivated agroecosystem has 5 and 10 earthworm species respectively. The abundance pattern in cultivated and non-cultivated agro-ecosystem was in the order of M. posthuma $>$ E. waltoni $>M$. houlleti $>O$. beatrix $>A$. alexandri and M. posthuma $>O$. beatrix $>M$. houllet $>E$. waltoni $>E$. incommodus $>A$. morris $>A$. alexandri $>M$. birmanica $>$ Polypheretima elongata $>$ Perionyx excavatus respectively (Fig. 1b). Out of all the reported species, M. posthuma was found to be the most abundant earthworm species in both cultivated as well non-cultivated agroecosystems with the occurrence at $56.81 \%$ sites. The Shannon-Wiener diversity index $(\mathrm{H})$, Margalef species richness index $\left(\mathrm{D}_{\mathrm{Mg}}\right)$ and Pielou species evenness (E) were ranged from 0 to $0.86,0$ to 0.64 and 0.78 to 1 respectively (Table 1 ). The different values of ShannonWiener diversity, species richness and species evenness index for the same number of earthworm individual at few sites were due to the difference in the number of earthworm species.

\section{Relation between physico-chemical properties of soil and earthworm abundance}

The physico-chemical analysis of soils of all sampling sites is given in Table 2. The texture of soil was found to be loam to sandy loam at maximum sites with sand (\%), silt (\%) and clay (\%) were in the range of 43.28-81.47, 5.3444.21 and $6.54-27.61$ respectively. The moisture content of the soil at each sampling site was more than $45 \%$. The earthworm species were distributed in the soil moisture range from 48-97\%, $\mathrm{pH}$ from 5.96-8.65, EC from 27.3-897.5 $\mu \mathrm{S}$, TDS from 27.45 to $166.5 \mathrm{mg} / \mathrm{L}$, OC from $1.01-9.53 \%, \mathrm{~N}$ from $0.12-2.68 \mathrm{~g} / \mathrm{Kg}, \mathrm{P}$ from $0.06-0.26 \mathrm{~g} /$ $\mathrm{Kg}$, K from 0.97 to $7.45 \mathrm{~g} / \mathrm{Kg}$, Ca from $1.18-107.34 \mathrm{~g} / \mathrm{Kg}$ and $\mathrm{Na}$ from 0.44 to $1.45 \mathrm{~g} / \mathrm{Kg}$.

The distribution and abundance of 8 earthworm species w.r.t. range of physico-chemical properties of soil at different sampling sites is given in Table 3 . The range of physico-chemical properties of soil for Polypheretima elongata, and Perionyx excavatus is not given due to their presence at a single site only. The M. posthuma, A. morrisi, $A$. alexandri, E. incommodus and $M$. birmanica were present in slightly alkaline soil while $E$. waltoni, $M$. houlleti, and $O$. beatrix were present from slightly acidic to slightly alkaline soil. The organic carbon (\%) range for $M$. posthuma (OC from 1.45 to 9.53) was high as compared to other species. High range of $\mathrm{N}(0.12-2.68 \mathrm{~g} / \mathrm{Kg})$ and $\mathrm{P}$ $(0.06-0.26 \mathrm{~g} / \mathrm{Kg})$ content was also observed at M. posthuma sampling sites which is due to the use of nitrogen and phosphorus in the form of fertilizers in the cultivated fields.

\section{Impact of soil properties on earthworm abundance}

The Principal component analysis (PCA) was used on 13 different variables of soil for 44 different sites to study the influence of soil properties on the distribution and abundance of earthworm species. The PCA analysis gives four different principal components (PC) i.e. PC1, PC2, 


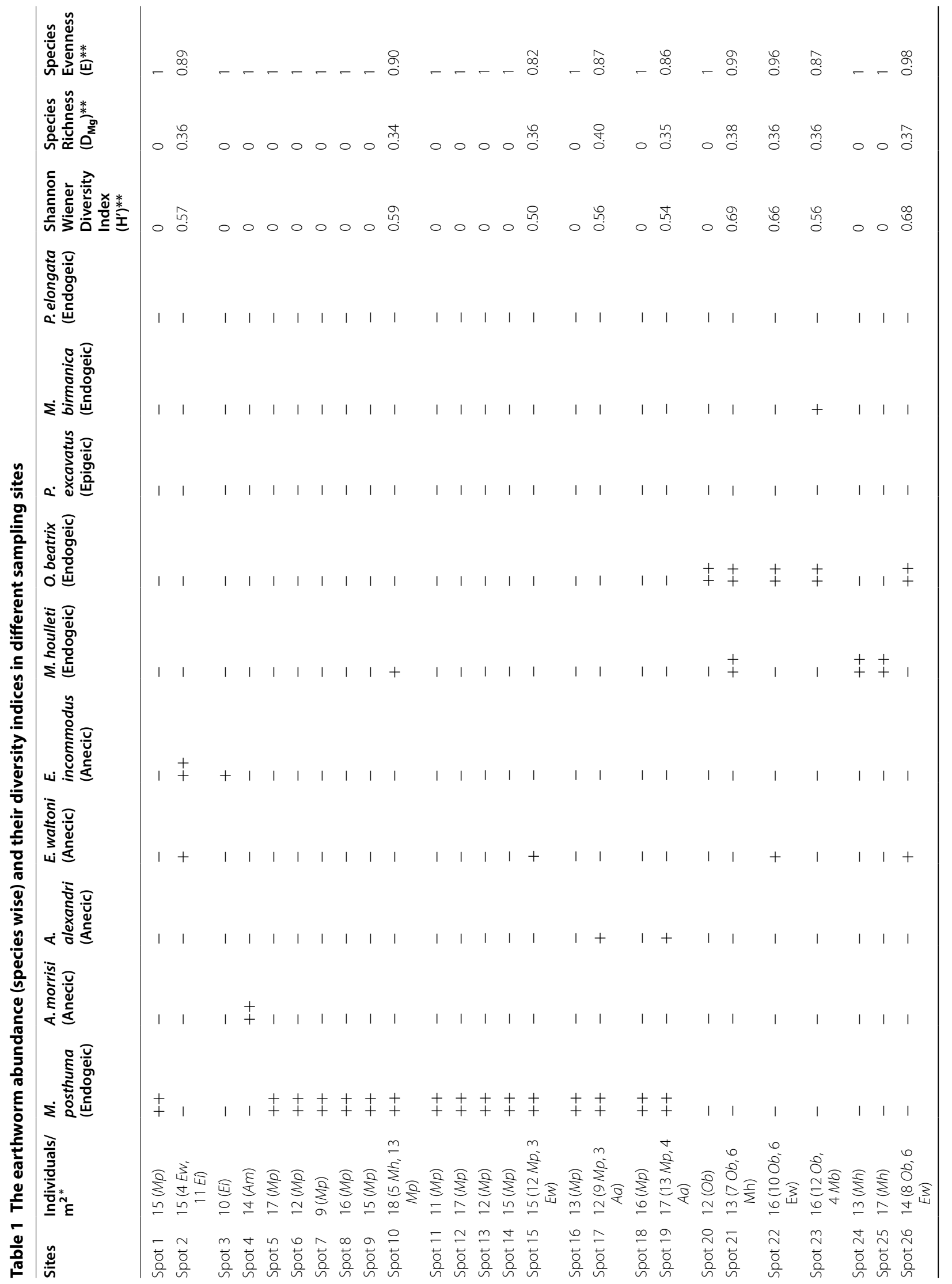


Singh et al. BMC Ecol $\quad$ (2020) 20:27

Page 4 of 14

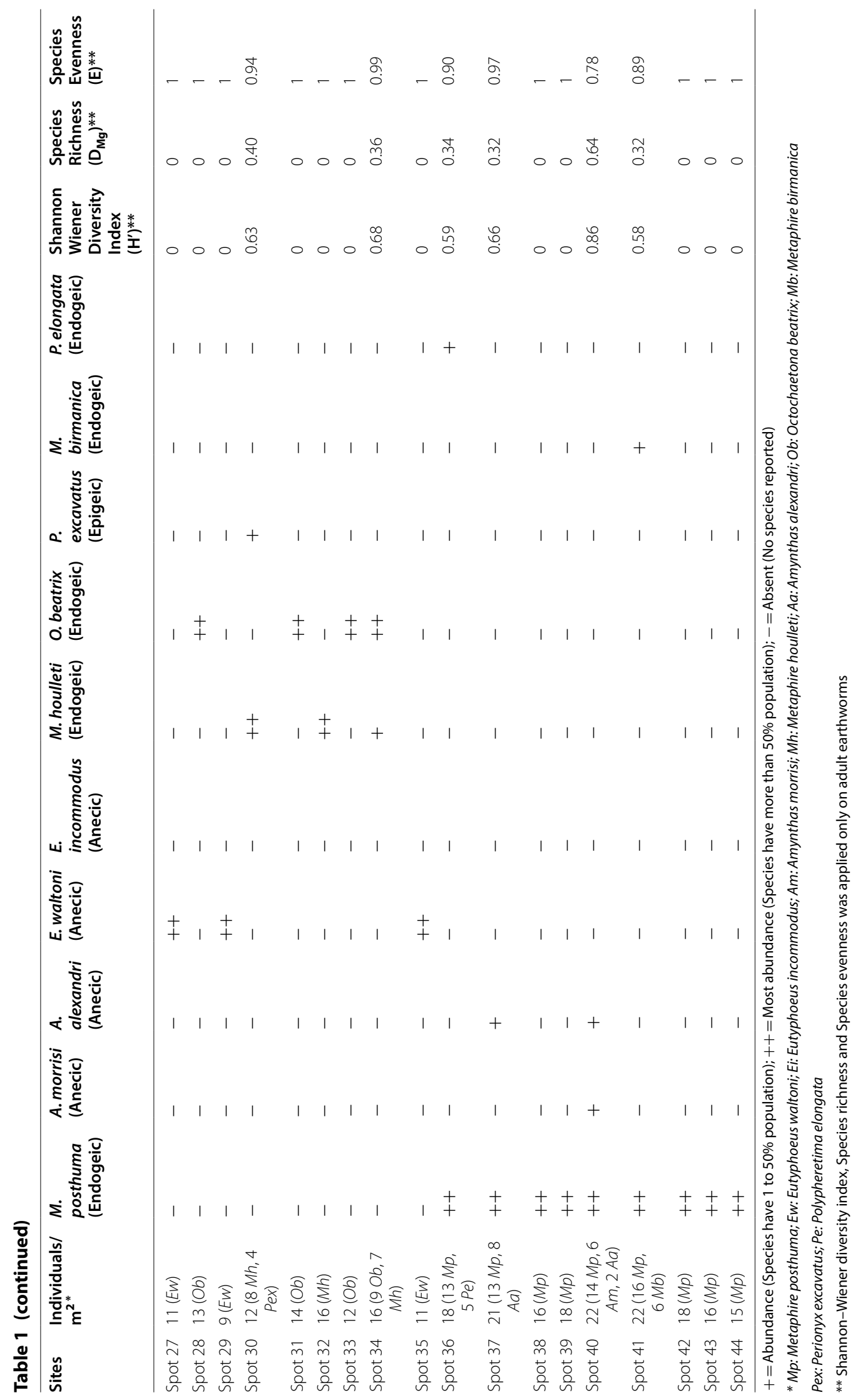




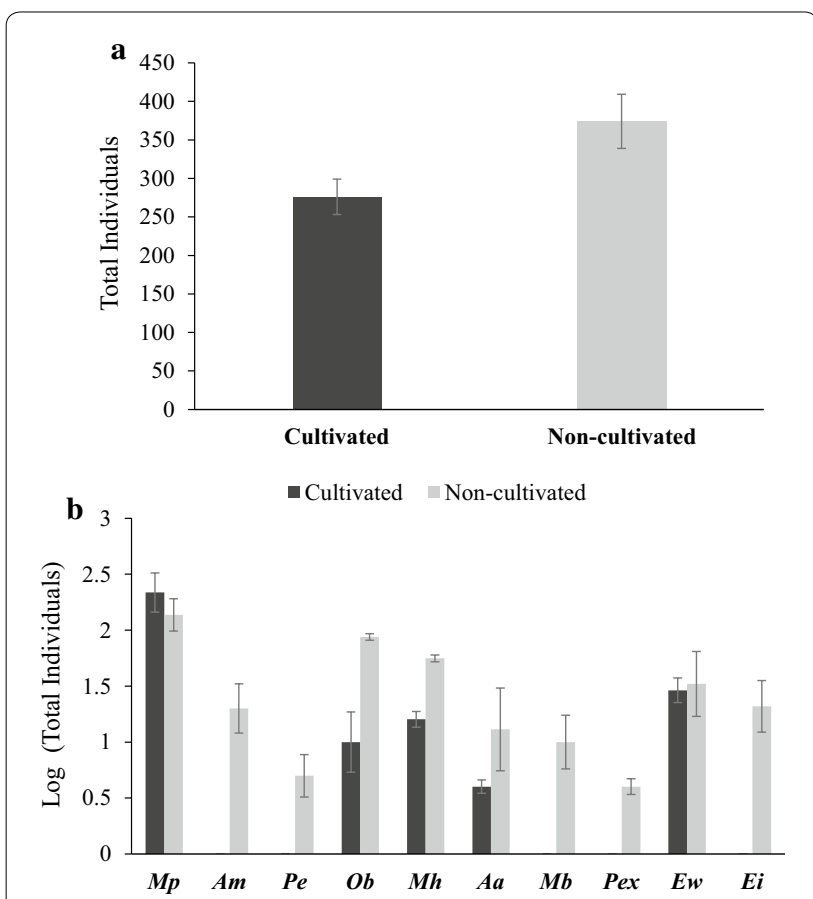

Fig. 1 The total number of individuals sampled (a) and total individuals sampled (log transformed) in each earthworm species (b) in cultivated and non-cultivated sampling sites

PC3 and PC4 which causing variance (\%) of 22.96, 19.37, 14.23 and 10.10 respectively (Table 4 ). As indicated by Liu et al. [18], the factors were considered weak, moderate and strong when absolute loading values were $<0.50$, $0.50-0.75$ and $>0.75$ respectively. The variance in $\mathrm{PC} 1$ is due to $\mathrm{pH}, \mathrm{EC}$, TDS, and $\mathrm{K}$; in PC2 is due to sand, clay and silt; in PC3 is due to Moisture and $\mathrm{OC}$; in PC4 is due to $\mathrm{Ca}, \mathrm{Na}, \mathrm{P}$ and $\mathrm{N}$. The first two components of the PCA i.e. PC1 $(22.96 \%)$ and PC2 (19.37\%) of physico-chemical variables account for $42.33 \%$ of total variance with positive strong loading of $\mathrm{pH}, \mathrm{EC}$, TDS and $\mathrm{K}$ in PC1 while strong negative loading of clay and strong positive loading of silt and sand in PC2 (Fig. 2a). On the other hand, PC1 $(22.96 \%)$ and PC3 (14.23\%) account for $37.19 \%$ of total variance with strong positive loading of $\mathrm{OC}$ and strong negative loading of moisture in PC3 (Fig. 2b). The principal component PC4 accounts for the variance of $10.10 \%$ with positive loading of Ca, N, Na \& P (Fig. 2c). The earthworm abundance and soil properties have significant direct relation (PERMANOVA, $\mathrm{F}=22.1, \mathrm{P}<0.05$; Mantel test, $\mathrm{R}=0.14, \mathrm{P}<0.05)$ and soil properties also favours the earthworm abundance at a particular site and vice versa.

\section{Discussion}

\section{Effect of land use pattern on earthworm diversity}

The abiotic factors, vegetation type and physico-chemical properties of soil determined the abundance of earthworms [1]. Metaphire posthuma was observed at maximum sampling sites including both cultivated and non-cultivated while Polypheretima elongata and Perionyx excavatus were restricted to a single site, least abundant and reported from non-cultivated sites. Thus, M. posthuma was found to be the most stable and adapted earthworm species in cultivated land use which corroborated with the findings of Singh et al. [1] who also observed the same results. The high abundance of $M$. posthuma at cultivated sites might be due to their endogeic ecological nature [1]. Mariotte et al. [19] also reported that earthworm species with endogeic ecological category were least affected as compare to epigeic and anecic earthworm species. On the other hand, ploughing damages the burrows of earthworm in the soil which directly disturbs anecic and epigeic earthworm species as compared to species with the endogeic ecological category. This might be the reason for the low abundance and diversity of anecic and epigeic species in agricultural fields as compared to gardens and nurseries [20]. On the other hand, in our study other endogeic earthworm species viz $M$. houlleti, O. beatrix, M. birmanica and Polypheretima elongata were also reported but their abundance is much less in cultivated fields as compare to non-cultivated fields. The reason for this may be due to agricultural practices. The more abundance of earthworm species was observed at margins of the paddy fields but no earthworm was reported inside fields because paddy cultivation requires intensive ploughing and water. This might be the reason for the abundance of earthworm at field margins. Thus, our study is corroborated with Frazão et al. [3] and van Schaik et al. [17] who also observed high density and species richness of earthworm in field margins as compared to the fields having wheat cultivation.

In the present study, the earthworm diversity indices were changed as the agro-ecosystem changed from cultivated to non-cultivated pattern. The highest values of diversity indices were observed in non-cultivated sites as compared to cultivated sites which were due to the availability of only one species of earthworm i.e. $M$. posthuma in cultivated sites as compare to non-cultivated sites. Solomou et al., [21] also observed that the diversity indices change from non-cultivated to cultivated agro-ecosystem. The agricultural management practices such as deep ploughing, fertilizer and pesticide application directly affect the earthworm species present within the soil which usually affects the diversity indices. Bartz et al. [22] also observed that 


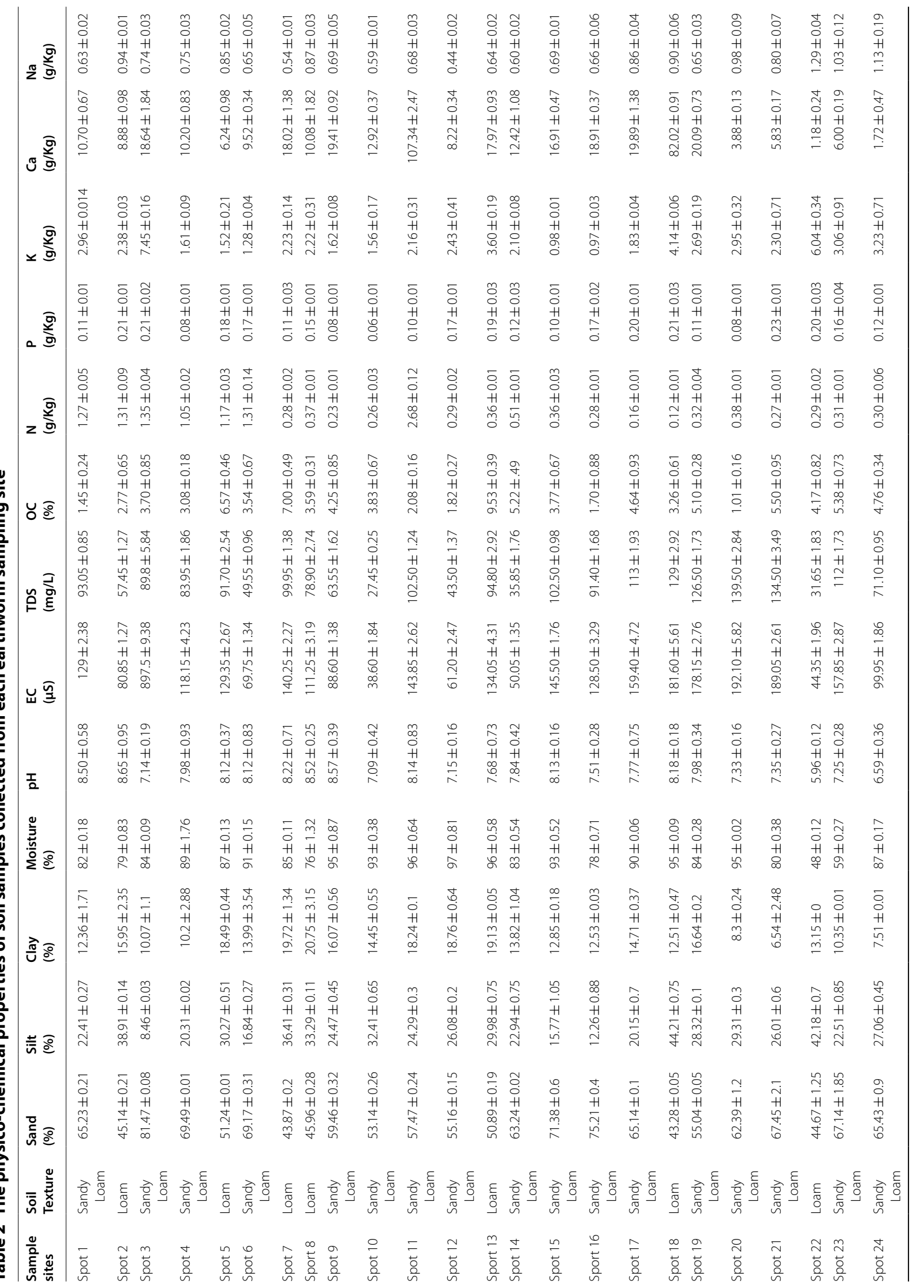




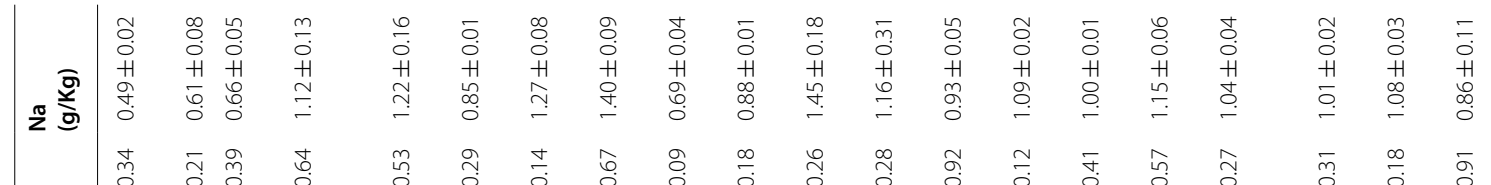

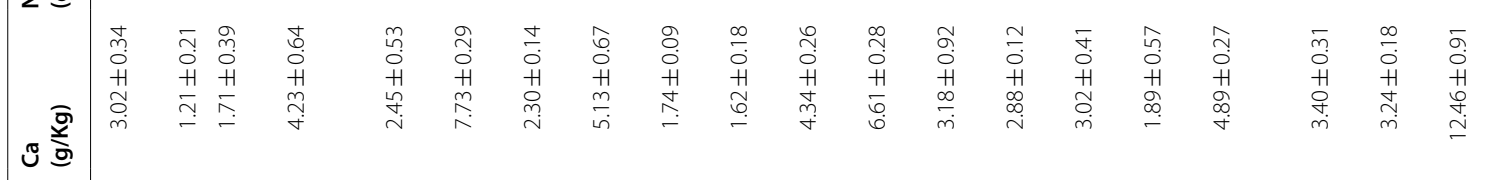

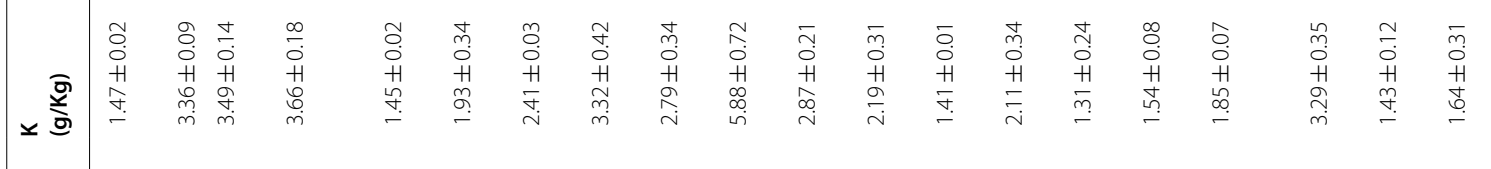

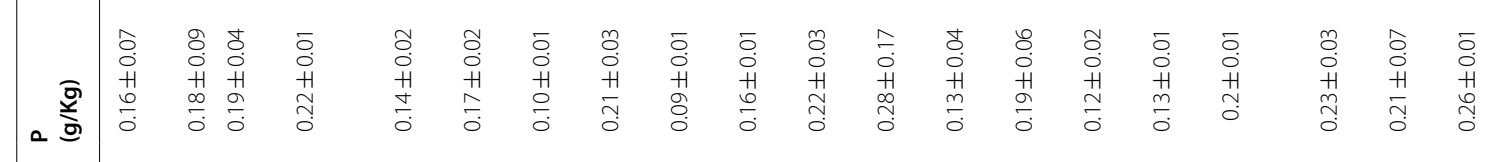

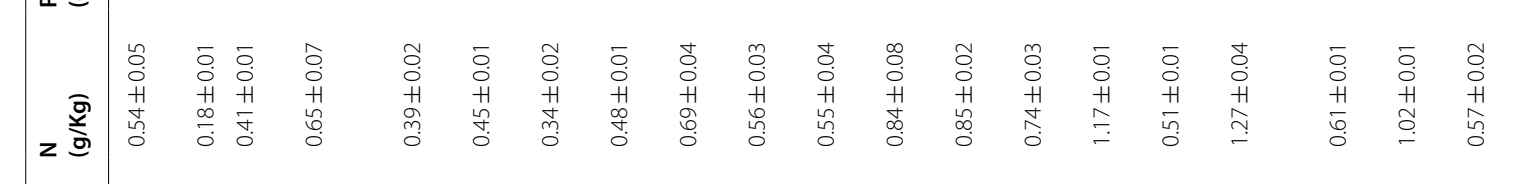

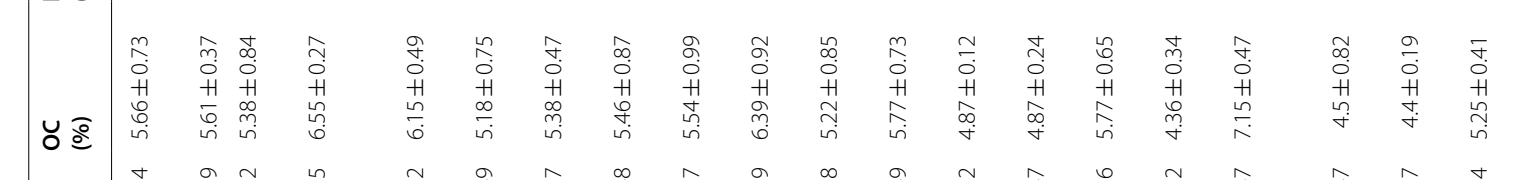

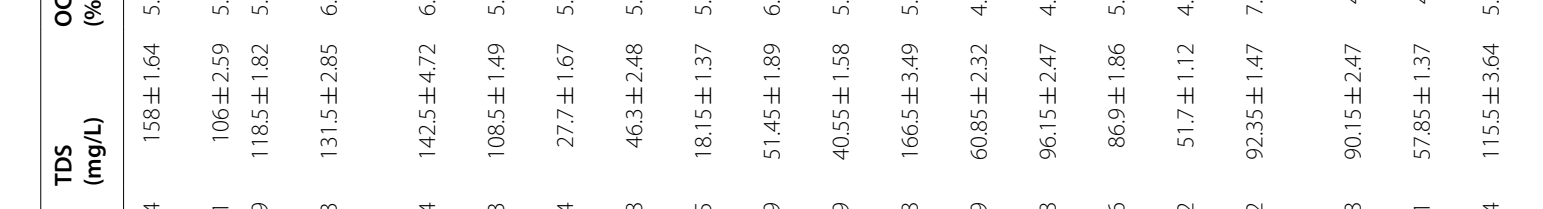

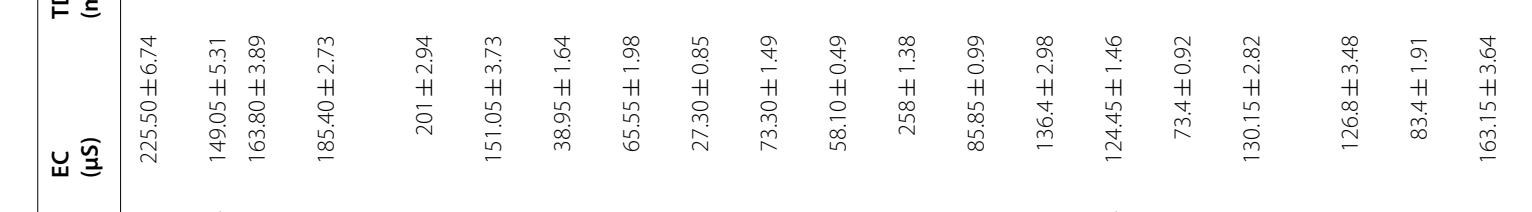

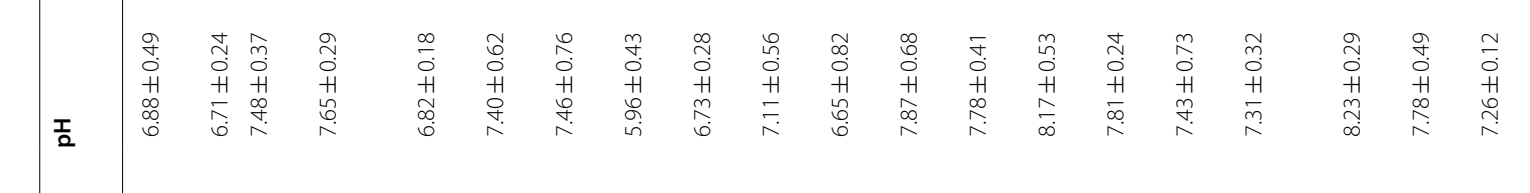

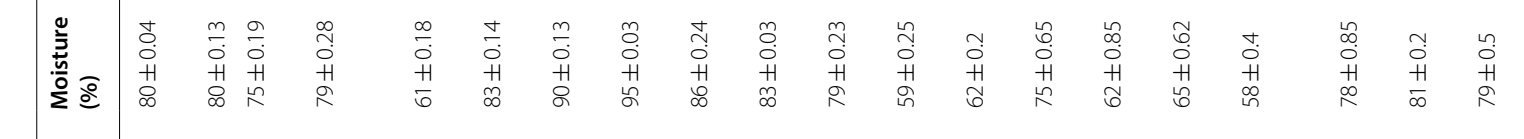

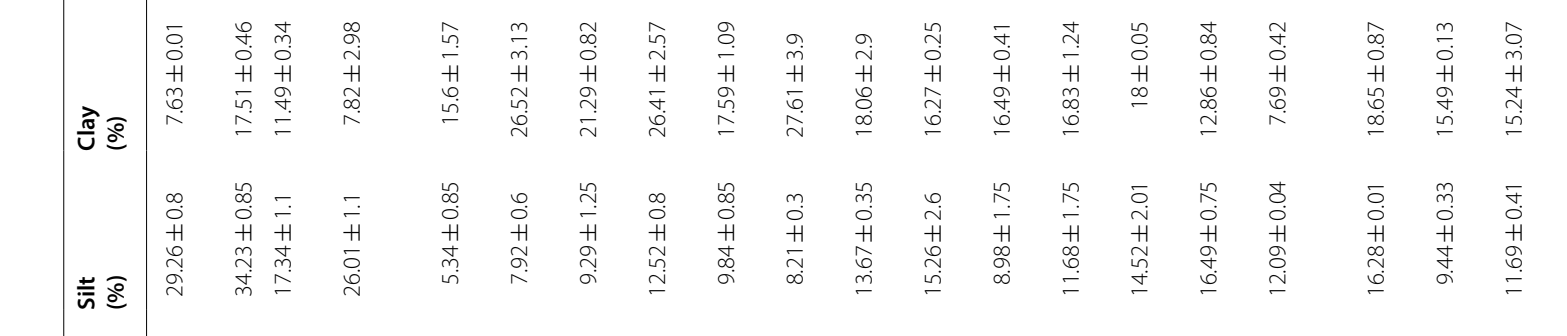

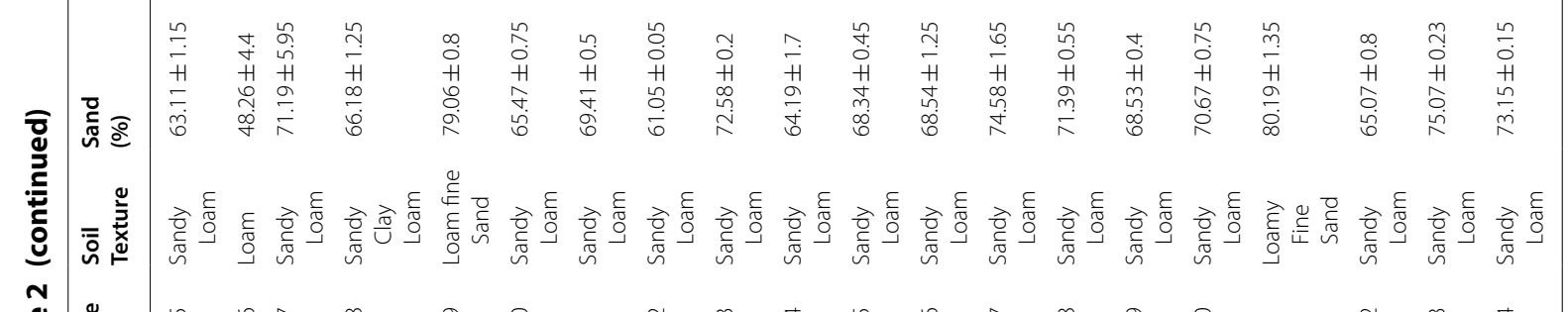

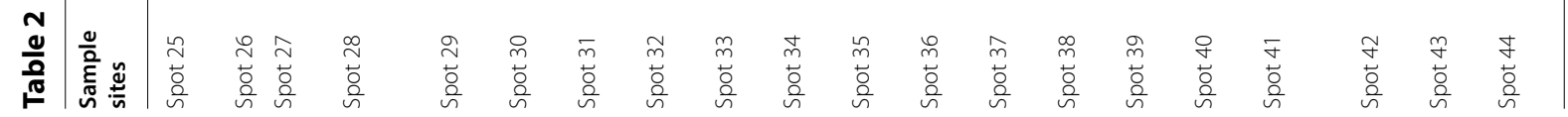




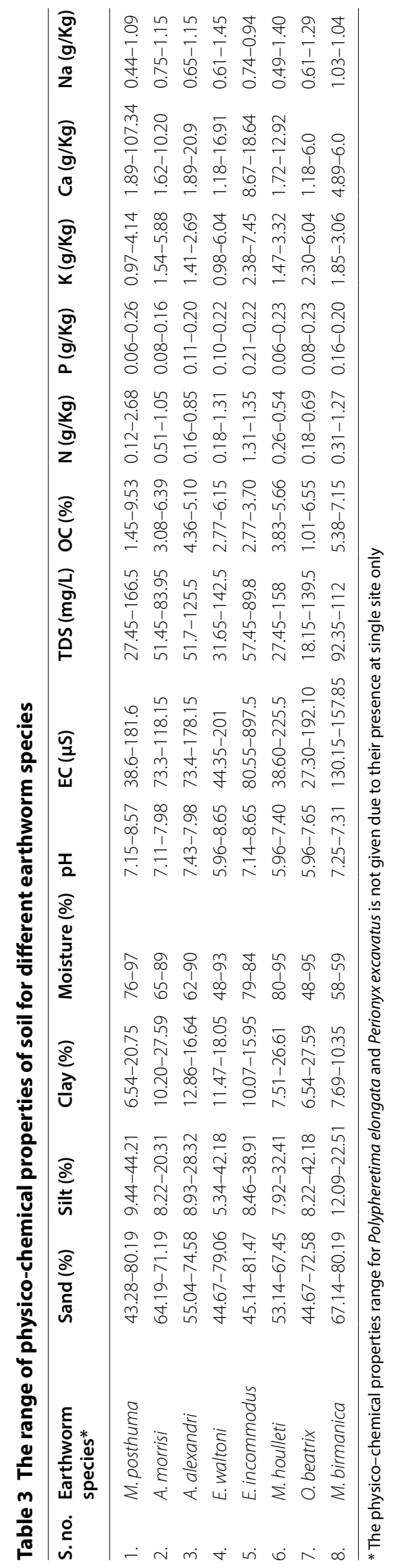


Table 4 The eigenvalues and principal components of soil variables along with variances in percentage

\begin{tabular}{lllll}
\hline Variables & PC1 & PC2 & PC3 & PC4 \\
\hline Sand & 0.127 & 0.933 & -0.006 & 0.118 \\
Silt & -0.047 & 0.954 & -0.076 & -0.105 \\
Clay & -0.167 & -0.898 & 0.169 & -0.031 \\
Moisture & 0.085 & 0.174 & -0.705 & -0.187 \\
pH & 0.748 & 0.113 & -0.010 & -0.272 \\
EC & 0.943 & -0.167 & -0.005 & -0.036 \\
TDS & 0.944 & -0.165 & -0.010 & -0.043 \\
OC & -0.009 & -0.039 & 0.962 & 0.137 \\
Ca & 0.164 & 0.345 & -0.267 & 0.614 \\
Na & -0.097 & -0.193 & -0.029 & 0.802 \\
K & 0.735 & 0.295 & -0.022 & 0.248 \\
P & 0.282 & 0.069 & 0.274 & 0.660 \\
N & 0.147 & -0.247 & -0.177 & 0.768 \\
Earthworms abundance & -0.378 & 0.427 & 0.390 & -0.149 \\
Eigenvalue & 3.215 & 2.712 & 1.992 & 1.414 \\
Variance (\%) & 22.96 & 19.37 & 14.23 & 10.10 \\
Cumulative variance (\%) & 22.96 & 42.33 & 56.57 & 66.67 \\
\hline
\end{tabular}

Extraction method: principal component analysis. rotation method: varimax with kaiser normalization

minimum ploughing has greater earthworm richness as compared to the site with conventional tillage. Margerie et al. [23] and Goswami [24] also supported our observation that diversity indices usually change from one sampling site to another due to changes in the habitat.

\section{Soil variables and earthworm abundance}

The physico-chemical properties of soil directly affect the earthworm abundance and hence diversity indices. In the present study, high contents of N, P and TDS were reported in the cultivated fields and these cultivated fields have also less earthworm diversity with restriction to single earthworm species. We have also observed that sites having the application of cattle dung as organic manure like in gardens have more earthworm species than agriculture land. The input of organic manures and nonconventional farming system also improves soil quality which promotes earthworm presence within the soil [21, 25]. Singh et al. [26] also reported that the use of sheep dung in the intensive grassland management increase the earthworm population and their abundance and number increase up to four times which directly affected the earthworm diversity indices [27]. The present study also reported that agricultural management practices such as ploughing, tillage etc. also has an effect on the abundance of earthworms at a particular site.
The principal component analysis was also applied to the 13 different physico-chemcial variables which resulted in total of 4 principal components (PC) which explained $66.67 \%$ of the total variance. The PC1 explained $22.96 \%$ of total variance which was due to $\mathrm{pH}$, EC, TDS and K. This validates the outcomes of Sanchez et al. [28] which explained that earthworm prefers soil having salt concentrations. The $\mathrm{pH}$ at a particular site is also an important factor for earthworm distribution as earthworms can survive only in neutral but also in slightly acidic to slightly alkaline soil conditions. Soil $\mathrm{pH}$ did not directly affect the abundance of earthworms at a particular site but indirectly $\mathrm{pH}$ drives other chemical processes in earthworms which affect nutrient availability [29]. In the present study, the $\mathrm{pH}$ of the soil varied from 5.96 to 8.6. The earthworm's species respond very quickly to variations in $\mathrm{pH}$ at a particular site and they are generally avoiding soil having $\mathrm{pH}$ values less than 4.5 , favoring $\mathrm{pH}$ between 5.0 and 7.4 [30]. McCallum et al. [31] also observed that diversity and abundance of earthworms are very low in soil having a $\mathrm{pH}$ near 4.5 . Most of the studies reported that earthworms can tolerate a $\mathrm{pH}$ range of 5.0 to 8.0 and an abundance of earthworms increase as $\mathrm{pH}$ was shifted from acidic or basic to neutral. De Wandeler et al. [16] also observed that the earthworm's abundance and diversity in soil increased with an increase in $\mathrm{pH}$ from acidic to neutral and maximum earthworm abundance was found near $\mathrm{pH}$ 7. The EC also plays a vital role in earthworm metabolism [32]. Thus, PC1 explained chemical factors for earthworm's distributions. The PC2 explained $19.37 \%$ of total variance respectively which was due to sand, silt and clay. Yvan et al. [33] described that soil texture also influences the activity and growth of earthworm. Higher clay content in soil favours growth and abundance of earthworm's species [34] which is clearly represented in our study. Thus, PC2 explained the soil texture factor. The PC3 explained $14.23 \%$ of total variance which was due to $\mathrm{OC}$ and moisture. According to Chan and Barchia [35], organic carbon is the critical factor for the earthworm distribution as it helps in determines the type and nature of food for an earthworm. Bartz et al. [22] and Jänsch et al. [36] also observed a significant relationship between soil OC and earthworm abundance. They observed that sites with high earthworm abundance have high soil OC content and vice versa. The presence of leaf litter in the soil also favors the earthworm population due to the easy availability of organic matter [37]. The Moisture is a critical factor for earthworm distribution due to the cutaneous mode of respiration [38]. Walsh and Johnson-Maynard [39] reported that earthworms were absent from the driest sites and their high density and biomass depend on local conditions like soil properties and management. Talavera 


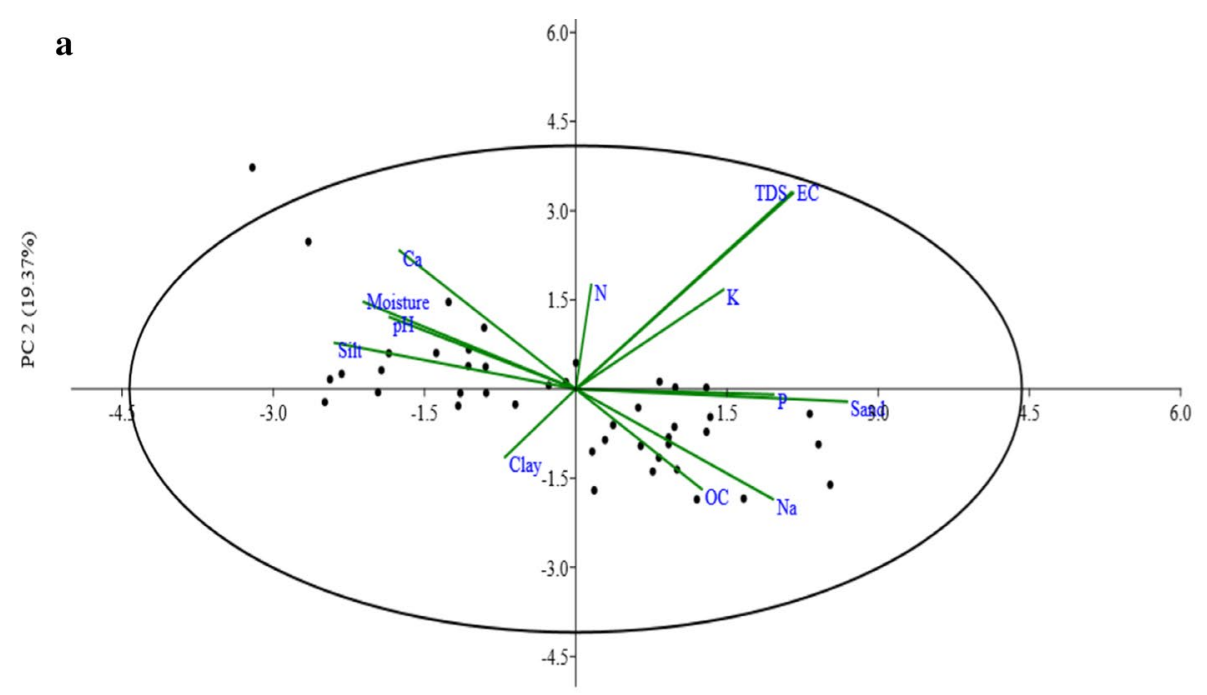

$\operatorname{PC} 1(22.96 \%)$
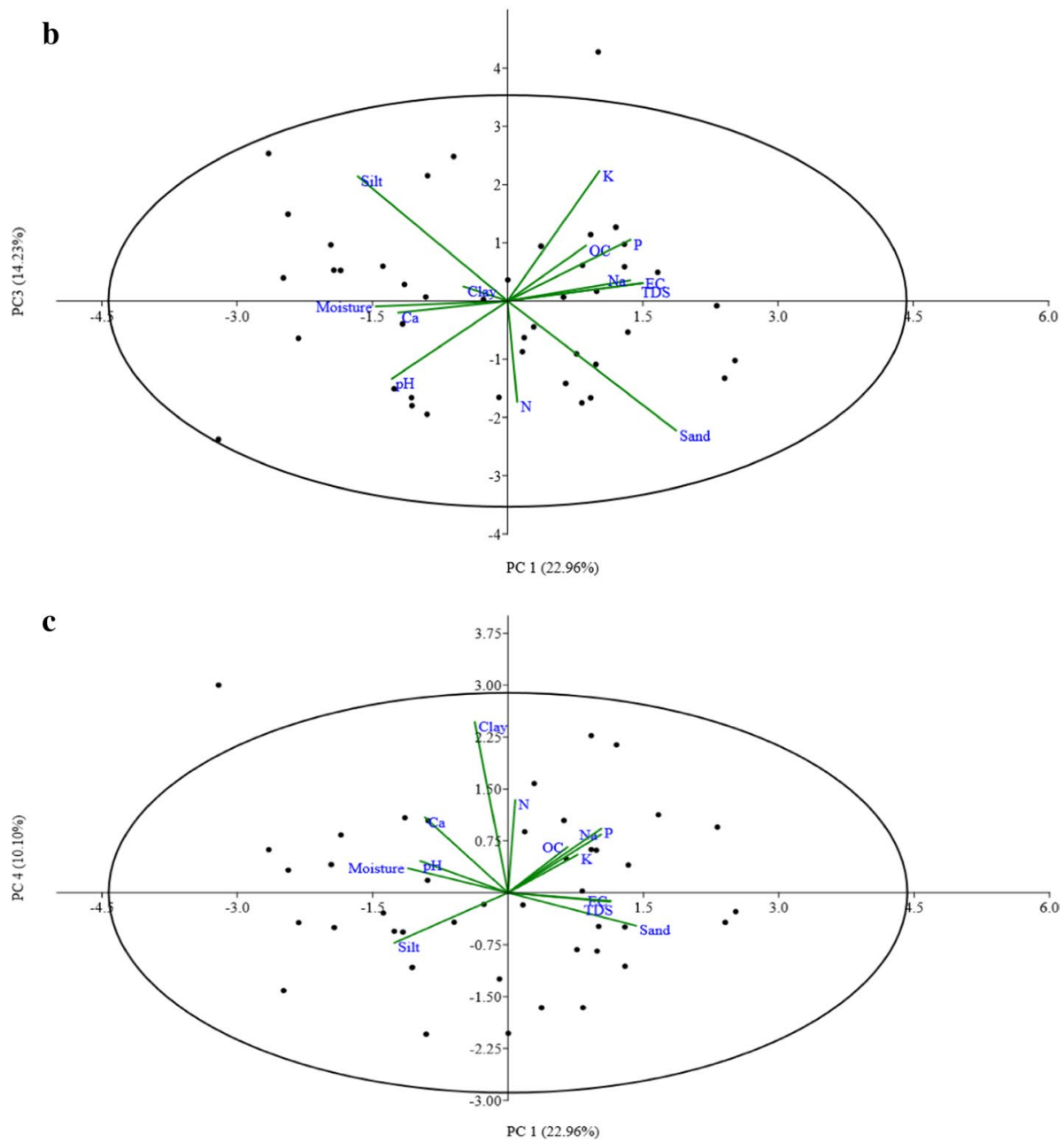

Fig. 2 Biplot of PCA of 13 different physico-chemical properties of soil, a PC1 vs PC2; b PC1 vs PC3; c PC1 vs PC4. The PC1, PC2, PC3 and PC4 explain $22.96 \%, 19.37 \%, 14.23 \%$ and $10.10 \%$ of variance respectively in datasets. The components with variance less than $10 \%$ were excluded. The Varimax rotation with Kaiser Normalization method was used for the extraction of principal components 
et al. [40] have reported that both moisture and $\mathrm{OC}$ are the key factors for the prediction of earthworm communities at a particular site. Thus, PC3 explains the growth factor. The PC4 explained $10.10 \%$ of variance which was due to $\mathrm{N}, \mathrm{Ca}, \mathrm{Na}$ and $\mathrm{P}$; which explain the edaphic factors for earthworm's distributions. Thus, PCA explained that earthworm communities and their diversity indices are directly correlated with the physico-chemical characteristics of soil at the particular site.

\section{Conclusion}

This study provides information about the pattern of earthworm diversity in cultivated and non-cultivated fields and how soil physico-chemical properties affect the earthworm diversity indices in different agro-ecosystem. It was concluded that cultivated fields having less earthworm diversity as compared to non-cultivated fields. The $M$. posthuma was observed at maximum sampling sites and found in all types of vegetation especially in the cultivated fields having paddy plantation while others endogeic earthworm species were absent in paddy plantation. The change in physico-chemical properties of soil also alters the earthworm diversity indices. The principal component analysis also showed that the physico-chemical properties of soil play a critical role in earthworm distribution. The diversity indices also change due to the conventional farming system which directly affects the earthworm abundance. The farmers should be aware of the roles of earthworms in soil and also must be encouraged to shift their agricultural practices from conventional to organic. These practices not only increase earthworm diversity and abundance but also helps to maintain soil enriched with various types of major and macro-nutrients.

\section{Methods}

\section{Site study}

The earthworm sampling was done during two consecutive years in monsoon and post-monsoon seasons of the year 2015 and 2016 in the district Kathua (Jammu \& Kashmir, India) (Fig. 3). This monsoon and post-monsoon period were chosen for sampling due to easy availability and high maturity of earthworms. The Kathua district is situated in $32^{\circ} 34^{\prime} \mathrm{N} 75^{\circ} 29^{\prime} \mathrm{E}$ with annual rainfall in this district is approximately $1672 \mathrm{~mm}$. The summer temperature arises as high as $48{ }^{\circ} \mathrm{C}$ in the plains and in winter temperature touches to sub-zero mainly in upper hilly areas. The area under Kathua district experiences a wide range of climate from subtropical to temperate areas. The major crop of the study site is paddy, wheat, barley, and maize.

\section{Earthworm sampling and Identification}

Earthworm's sampling was done at 44 sites having cultivated and non-cultivated agro-ecosystem which were chosen randomly (Additional file 1: Table S1). The collections of earthworms were mainly done during their activation period i.e. morning by using hand sorting $(1 \mathrm{~m} \times 1 \mathrm{~m}$ area) followed by AITC extraction solution [15] to collect deep burrowing earthworm species. The collected earthworms from all the diverse sites with a reasonable amount of soil were placed in plastic bags, named with the site name, sampling date, etc. The earthworms were washed with tap water and narcotized with $70 \%$ ethyl alcohol. The narcotized earthworms were transferred to the flat tray with a $5 \%$ formalin solution in a straight position for 4-6 $\mathrm{h}$ followed by preservation in test tubes containing $5 \%$ formalin. All the test tubes were labeled with the place of collection, date of collection and their habitat. The earthworms were identified according to the keys provided by Julka [41].

\section{Physico-chemical analysis of soil}

The soil samples were analyzed for texture, total dissolved solids (TDS), $\mathrm{pH}$, electrical conductivity (EC), organic carbon $(\mathrm{OC})$, nitrogen $(\mathrm{N})$, sodium $(\mathrm{Na})$, calcium $(\mathrm{Ca})$, phosphorus $(\mathrm{P})$, potassium $(\mathrm{K})$. The method of Bouyoucos [42] as used for soil texture analysis. The content of $\mathrm{pH}, \mathrm{EC}$, and TDS was analyzed by making the suspension of 1:10 (soil sample: distilled water) using a shaker and finally measured with a digital meter (Eutech Instruments). The $\mathrm{OC}$ was measured by using Nelson and Sommers [43] method after igniting the soil samples in a muffle furnace at $550{ }^{\circ} \mathrm{C}$. The $\mathrm{N}$ was analyzed according to Bremner and Mulvaney [44] method after digesting the soil sample with concentrated $\mathrm{H}_{2} \mathrm{SO}_{4}$ followed by running the sample in Kjeldahl assembly and finally titration was done with $0.01 \mathrm{~N} \mathrm{HCl}$. The process of John [45] was used for phosphorus estimation after digesting the soil with 1:4 of perchloric acid and nitric acid respectively followed by using a spectrophotometer (Systronics). The content of $\mathrm{Na}, \mathrm{K}$ and $\mathrm{Ca}$ was analyzed from samples digested for phosphorus by using Flame Photometer-128 (Systronics).

\section{Statistical analysis}

The data for physico-chemical properties of the soil is represented as mean \pm S.E. of triplicate data. The Shannon-Wiener index, species richness index and species evenness for each sampling site were also calculated by using standard calculation as suggested by Shannon and Wiener [46], Margalef [47] and Pielou [48] respectively. Principal Component Analysis (PCA) was used to know the major components in the soil with one or more variable which affects the diversity 


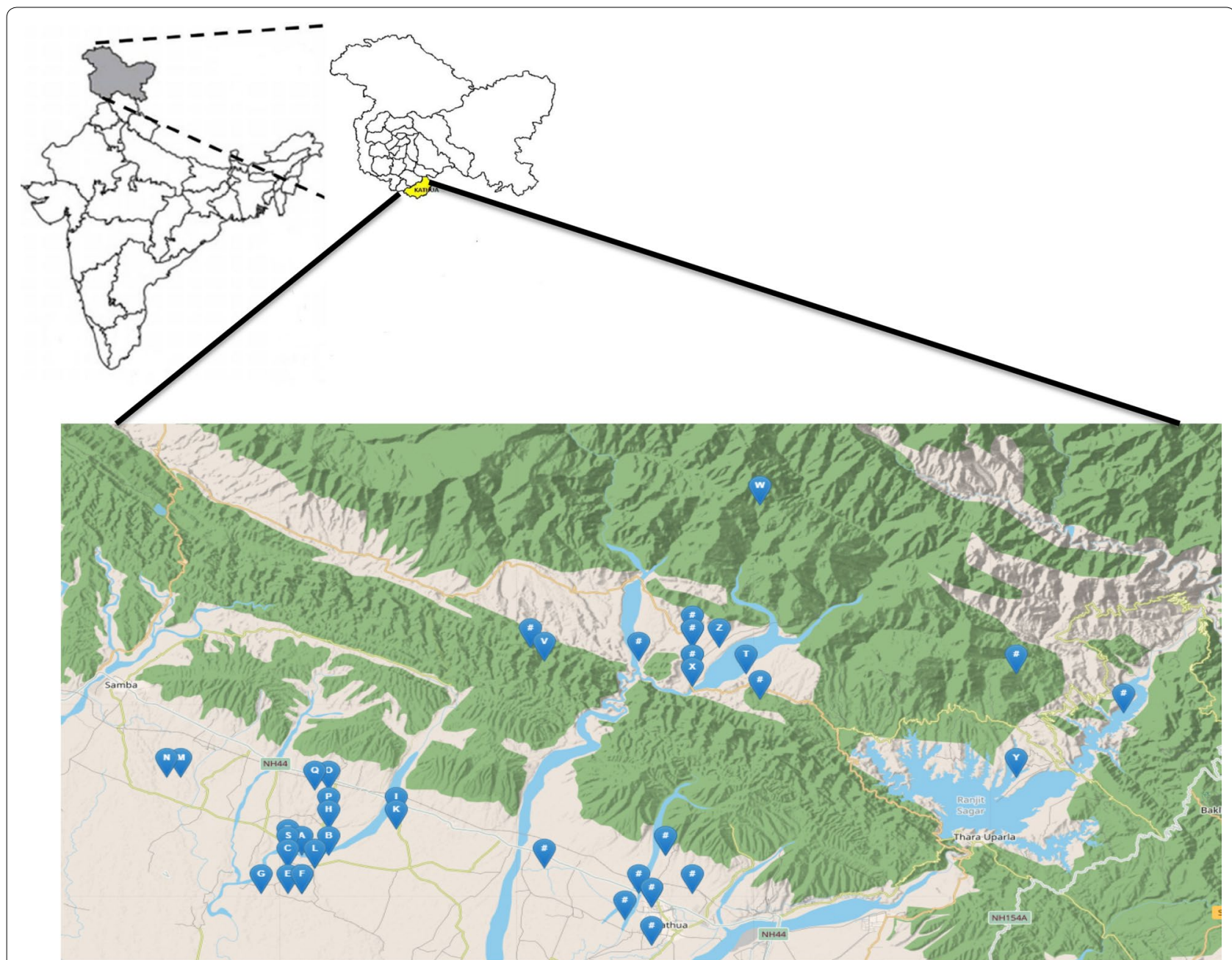

Fig. 3 Map showing the location of study sites

of earthworms at a particular site. PERMANOVA and Mantel test were also applied to test the relationship between soil variables and earthworm abundance by using similarity matrices and the resemblance between the matrices was done by using Bray-Curtis similarity measures with 9999 random permutations. The past statistical software (version 3) and SPSS 16 (version 21) programme were used for the statistical analysis of the data.

\section{Supplementary information}

Supplementary information accompanies this paper at https://doi. org/10.1186/s12898-020-00296-5.

Additional file 1: Table S1. The different sampling sites along with their agroecosystem, vegetation and GPS coordinates.

\section{Abbreviations}

PCA: Principal component analysis; PC: Principal component; PERMANOVA: Permutational multivariate analysis of variance; S.E: Standard error; AITC: Allyl isothiocyanate; TDS: Total dissolved solids; EC: Electrical conductivity; OC: Organic carbon; N: Nitrogen; Na: Sodium; Ca: Calcium; P: Phosphorus; K: Potassium; $\mathrm{HCl}$ : Hydrochloric acid; $\mathrm{H}_{2} \mathrm{SO}_{4}$ : Sulphuric acid; $\mathrm{H}^{\prime}$ : Shannon-Wiener Diversity Index; $\mathrm{D}_{\mathrm{Mg}}$ : Margalef species richness index; E: Pielou species evenness; Mp: Metaphire posthuma; Ew: Eutyphoeus waltoni; Ei: Eutyphoeus incommodus; Am: Amynthas morrisi; Mh: Metaphire houlleti; Aa: Amynthas alexandri; Ob: Octochaetona beatrix; Mb: Metaphire birmanica; Pex: Perionyx excavatus; Pe: Polypheretima elongata.

\section{Acknowledgements}

We acknowledge the University Grant Commission-UPE (University with Potential for Excellence) and Science \& Engineering Research Board, Department of Science and Technology, New Delhi. We also acknowledge the Department of Botanical and Environmental Sciences, Guru Nanak Dev University, Amritsar, and Post Graduate Department of Zoology, Khalsa College Amritsar for providing the necessary infrastructure and lab facility to carry out the research work. Authors are also very grateful to Dr. J. M. Julka (Retd. Scientist, Zoological Survey of India), Shoolini University, Solan (Himachal Pradesh, India) for affirmation of earthworms species. We are also thankful to 
anonymous reviewers for their constructive comments which improved the manuscript.

\section{Authors' contributions}

The paper was conceived and designed by: SS, JS and APV. The sampling of earthworms and analysis of soil samples were done by SS, AS and KK. The data and articles were analyzed by JS and SS. The manuscript's first draft was written by SS. The critical revisions and the final version were done by APV and JS. All authors have read and approved the final manuscript.

\section{Funding}

Not applicable.

\section{Availability of data and materials}

The data sets used and/or interpreted during the present research are accessible from the Corresponding author on reasonable request.

\section{Ethics approval and consent to participate}

The sampling of earthworms did not require permission and the species are not classified as endangered, and are not under any protection in any of the sampled areas.

\section{Consent for publication}

Not applicable.

\section{Competing interests}

The authors declare that there is no competing interest.

Received: 12 August 2019 Accepted: 29 April 2020

Published online: 07 May 2020

\section{References}

1. Singh S, Singh J, Vig AP. Effect of abiotic factors on the distribution of earthworms in different land use patterns. J Basic Appl Zool. 2016;74:4150. https://doi.org/10.1016/j.jobaz.2016.06.001.

2. Schon NL, Mackay AD, Gray RA, Van Koten C, Dodd MB. Influence of earthworm abundance and diversity on soil structure and the implications for soil services throughout the season. Pedobiologia. 2017;62:41-7. https://doi.org/10.1016/j.pedobi.2017.05.001.

3. Frazão J, de Goede RG, Brussaard L, Faber JH, Groot JC, Pulleman MM Earthworm communities in arable fields and restored field margins, as related to management practices and surrounding landscape diversity. Agric Ecosyst Environ. 2017;248:1-8. https://doi.org/10.1016/j. agee.2017.07.014

4. Schmidt O, Clements RO, Donaldson G. Why do cereal-legume intercrops support large earthworm populations? Appl Soil Ecol. 2003;22(2):181-90. https://doi.org/10.1016/S0929-1393(02)00131-2.

5. Baker GH, Carter PJ, Curry JP, Cultreri O, Beck A. Clay content of soil and its influence on the abundance of Aporrectodea trapezoides Duges (Lumbricidae). Appl Soil Ecol. 1998;9(1):333-7. https://doi.org/10.1016/S0929 -1393(98)00085-7.

6. Baker $\mathrm{GH}$, Whitby WA. Soil pH preferences and the influences of soil type and temperature on the survival and growth of Aporrectodea longa (Lumbricidae): the 7th international symposium on earthworm ecology. Cardiff. Wales. 2002. Pedobiologia. 2003;47(5-6):745-53. https://doi. org/10.1078/0031-4056-00254.

7. Perreault JM, Whalen JK. Earthworm burrowing in laboratory microcosms as influenced by soil temperature and moisture. Pedobiologia. 2006;50(5):397-403. https://doi.org/10.1016/j.pedobi.2006.07.003.

8. Jiménez JJ, Decaëns T, Amézquita E, Rao I, Thomas RJ, Lavelle P. Shortrange spatial variability of soil physico-chemical variables related to earthworm clustering in a neotropical gallery forest. Soil Biol Biochem. 2011;43(5):1071-80. https://doi.org/10.1016/j.soilbio.2011.01.028.

9. Sharpley A, McDowell R, Moyer B, Littlejohn R. Land application of manure can influence earthworm activity and soil phosphorus distribution. Commun Soil Sci Plant Anal. 2011;42(2):194-207. https://doi. org/10.1080/00103624.2011.535070.
10. Pelosi C, Barot S, Capowiez Y, Hedde M, Vandenbulcke F. Pesticides and earthworms. A review. Agron Sustain Dev. 2014;34(1):199-228. https:// doi.org/10.1007/s13593-013-0151-z.

11. Pelosi C, Pey B, Hedde M, Caro G, Capowiez Y, Guernion M, Peigné J, Piron $D$, Bertrand $M$, Cluzeau D. Reducing tillage in cultivated fields increases earthworm functional diversity. Appl Soil Ecol. 2014;83:79-86. https://doi. org/10.1016/j.apsoil.2013.10.005.

12. Crittenden SJ, Eswaramurthy T, De Goede RG, Brussaard L, Pulleman MM. Effect of tillage on earthworms over short-and medium-term in conventional and organic farming. Appl Soil Ecol. 2014;83:140-8. https:// doi.org/10.1016/j.apsoil.2014.03.001.

13. Blouin M, Hodson ME, Delgado EA, Baker G, Brussaard L, Butt KR, Dai J, Dendooven L, Pérès G, Tondoh JE, Cluzeau D. A review of earthworm impact on soil function and ecosystem services. Eur J Soil Sci. 2013;64(2):161-82. https://doi.org/10.1111/ejss.12025.

14. Singh S, Singh J, Vig AP. Earthworm as ecological engineers to change the physico-chemical properties of soil: soil vs vermicast. Ecol Eng. 2016:90:1-5. https://doi.org/10.1016/j.ecoleng.2016.01.072

15. Singh J, Singh S, Bhat SA, Vig AP, Schädler M. Eco-friendly method for the extraction of earthworms: comparative account of formalin, AITC and Allium cepa as extractant. Appl Soil Ecol. 2018;124:141-5. https://doi. org/10.1016/j.apsoil.2017.11.007.

16. De Wandeler H, Sousa-Silva R, Ampoorter E, Bruelheide H, Carnol M, Dawud SM, Dănilă G, Finer L, Hättenschwiler S, Hermy M, Jaroszewicz B. Drivers of earthworm incidence and abundance across European forests. Soil Biol Biochem. 2016;99:167-78. https://doi.org/10.1016/j.soilb io.2016.05.003.

17. van Schaik L, Palm J, Klaus J, Zehe E, Schröder B. Potential effects of tillage and field borders on within-field spatial distribution patterns of earthworms. Agric Ecosyst Environ. 2016;228:82-90. https://doi.org/10.1016/j. agee.2016.05.015.

18. Liu CW, Lin KH, Kuo YM. Application of factor analysis in the assessment of groundwater quality in a blackfoot disease area in Taiwan. Sci Total Environ. 2003;313(1-3):77-89. https://doi.org/10.1016/S0048-9697(02)00683 $-6$.

19. Mariotte P, Le Bayon RC, Eisenhauer N, Guenat C, Buttler A. Subordinate plant species moderate drought effects on earthworm communities in grasslands. Soil Biol Biochem. 2016;96:119-27. https://doi.org/10.1016/j. soilbio.2016.01.020

20. Suthar S. Earthworm communities a bioindicator of arable land management practices: a case study in semiarid region of India. Ecol indic. 2009:9(3):588-94. https://doi.org/10.1016/j.ecolind.2008.08.002.

21. Solomou AD, Sfougaris AI, Vavoulidou EM, Csuzdi C. Species richness and density of earthworms in relation to soil factors in olive orchard production systems in Central Greece. Commun Soil Sci Plant Anal. 2013:44(14):301-11. https://doi.org/10.1080/00103624.2013.741904.

22. Bartz ML, Pasini A, Brown GG. Earthworms as soil quality indicators in Brazilian no-tillage systems. Appl Soil Ecol. 2013;69:39. https://doi. org/10.1016/j.apsoil.2013.01.011.

23. Margerie P, Decaëns T, Bureau F, Alard D. Spatial distribution of earthworm species assemblages in a chalky slope of the Seine Valley (Normandy, France). Eur J Soil Biol. 2001;37(4):291-6. https://doi.org/10.1016/S1164 -5563(01)01100-1.

24. Goswami R. Determination of ecological diversity indices to assess the interrelationship between earthworm diversity and different habitats of Indian Botanic garden, Howrah, India. Biol Forum. 2015;7(1):128.

25. Singh J, Singh S, Vig AP, Bhat SA, Hundal SS, Yin R, Schädler M. Conventional farming reduces the activity of earthworms: assessment of genotoxicity test of soil and vermicast. Agri Nat Res. 2018;52(4):366-70. https:// doi.org/10.1016/j.anres.2018.10.012.

26. Singh J, Cameron E, Reitz T, Schädler M, Eisenhauer N. Grassland management effects on earthworm communities under ambient and future climatic conditions. Eur J Soil Sci. 2020. https://doi.org/10.1111/ejss.12942

27. Bacher MG, Fenton O, Bondi G, Creamer RE, Karmarkar M, Schmidt O. The impact of cattle dung pats on earthworm distribution in grazed pastures. BMC Ecol. 2018;18(1):1-12. https://doi.org/10.1186/s12898-018-0216-6. 
28. Sanchez EG, Munoz B, Garvin MH, Jesus JB, Cosín DD. Ecological preferences of some earthworm species in southwest Spain. Soil Biol Biochem. 1997;29(3-4):313-6. https://doi.org/10.1016/S0038-0717(96)00169-1.

29. Cesarz S, Craven D, Dietrich C, Eisenhauer N. Effects of soil and leaf litter quality on the biomass of two endogeic earthworm species. Eur J Soil Biol. 2016;77:9-16. https://doi.org/10.1016/j.ejsobi.2016.09.002.

30. Curry JP, Schmidt O. The feeding ecology of earthworms-a review. Pedobiologia. 2007;50(6):463-77. https://doi.org/10.1016/j.pedobi.2006.09.001.

31. McCallum HM, Wilson JD, Beaumont D, Sheldon R, O'Brien MG, Park KJ. A role for liming as a conservation intervention? Earthworm abundance is associated with higher soil $\mathrm{pH}$ and foraging activity of a threatened shorebird in upland grasslands. Agri Ecosys Environ. 2016;223:182-9. https://doi.org/10.1016/j.agee.2016.03.005.

32. MirTA, Najar IA. Earthworm from doodhpathri (Budgam), Jammu and Kashmir. India. Int Res J Environ Sci. 2016;5:33-9.

33. Yvan C, Stéphane S, Stéphane C, Pierre B, Guy R, Hubert B. Role of earthworms in regenerating soil structure after compaction in reduced tillage systems. Soil Biol Biochem. 2012;55:93-103. https://doi.org/10.1016/j. agee.2016.03.005.

34. Nordstrom S, Rundgren S. Environmental factors and lumbricid associations in southern Sweden. Pedobiologia. 1974;14:1-27.

35. Chan KY, Barchia I. Soil compaction controls the abundance, biomass and distribution of earthworms in a single dairy farm in south-eastern Australia. Soil Till Res. 2007;94(1):75-82. https://doi.org/10.1016/j.still 2006.07.006

36. Jänsch S, Steffens L, Höfer H, Horak F, Roß-Nickoll M, Russell D, Toschki A, Römbke J. State of knowledge of earthworm communities in German soils as a basis for biological soil quality assessment. Soil Org. 2013;85:215-33.

37. Singh S, Singh J, Sharma A, Vig AP, Ahmed S. First report of the earthworm Pontoscolex corethrurus (Müller, 1857) from Punjab, India. Int Lett Nat Sci. 2018;68:1-8. https://doi.org/10.18052/www.scipress.com/ILNS.68.1.

38. Sharma RK, Bharadwaj P. Earthworm diversity in trans-gangetic habitats of Haryana. India. Res J Agri For Sci. 2014;2(2):1-7.
39. Walsh CL, Johnson-Maynard JL. Earthworm distribution and density across a climatic gradient within the Inland Pacific Northwest cereal production region. Appl Soil Ecol. 2016;104:104-10. https://doi.org/10.1016/j. apsoil.2015.12.010.

40. Talavera JA, Cunha L, Arévalo JR, Talavera IP, Kille P, Novo M. Anthropogenic disturbance and environmental factors drive the diversity and distribution of earthworms in São Miguel Island (Azores, Portugal). Appl Soil Ecol. 2020. https://doi.org/10.1016/j.apsoil.2019.06.004.

41. Julka JM. Know your Earthworms, Rashtriya Vigyan Evam Prodyogiki Sanchar Parishad (RVPSP) Solan (HP), 2008: 40-47.

42. Bouyoucos GJ. Hydrometer method improved for making particle size analyses of soils. Agron J. 1962;54(5):464-5. https://doi.org/10.2134/agron j1962.00021962005400050028x.

43. Nelson DW, Sommers LE. Total carbon, organic carbon, and organic matter. Methods Soil Anal. 1996;5:961-1010.

44. Bremner JM, Mulvaney RG. Nitrogen total. In: Page AL, Miller RH, Keeney DR, editors. Methods of Soil Analysis. Madison: Am Sco Agron; 1982. p. 575-624.

45. John MK. Colorimetric determination of phosphorus in soil and plant materials with ascorbic acid. Soil Sci. 1970;109(4):214-20.

46. Shannon CE, Wiener W. The Mathematical Theory of Communication. Urbana. University of Illinois Press. 1949; 177.

47. Margalef R. Temporal succession and spatial heterogeneity in phytoplankton. In: Buzzati-Traverso A, editor. Perspectives in Marine Biology. Berkeley: Univ Calif Press; 1958. p. 323-47.

48. Pielou EC. The measurement of diversity in different types of biological collections. JTheor Biol. 1996. https://doi.org/10.1016/00225193(66)90013-0.

\section{Publisher's Note}

Springer Nature remains neutral with regard to jurisdictional claims in published maps and institutional affiliations.
Ready to submit your research? Choose BMC and benefit from:

- fast, convenient online submission

- thorough peer review by experienced researchers in your field

- rapid publication on acceptance

- support for research data, including large and complex data types

- gold Open Access which fosters wider collaboration and increased citations

- maximum visibility for your research: over $100 \mathrm{M}$ website views per year

At BMC, research is always in progress.

Learn more biomedcentral.com/submissions 